\title{
Multi-objective optimization of methane production system from biomass through anaerobic digestion
}

\author{
Li, Weijun; Huusom, Jakob Kjøbsted; Zhou, Zhimao; Nie, Yi; Xu, Yajing; Zhang, Xiangping
}

Published in:

Chinese Journal of Chemical Engineering

Link to article, DOI:

10.1016/j.cjche.2018.01.001

Publication date:

2018

Document Version

Peer reviewed version

Link back to DTU Orbit

Citation (APA):

Li, W., Huusom, J. K., Zhou, Z., Nie, Y., Xu, Y., \& Zhang, X. (2018). Multi-objective optimization of methane production system from biomass through anaerobic digestion. Chinese Journal of Chemical Engineering, 26(10), 2084-2092. https://doi.org/10.1016/j.cjche.2018.01.001

\section{General rights}

Copyright and moral rights for the publications made accessible in the public portal are retained by the authors and/or other copyright owners and it is a condition of accessing publications that users recognise and abide by the legal requirements associated with these rights.

- Users may download and print one copy of any publication from the public portal for the purpose of private study or research.

- You may not further distribute the material or use it for any profit-making activity or commercial gain

- You may freely distribute the URL identifying the publication in the public portal 


\section{Accepted Manuscript}

Multi-objective optimization of methane production system from biomass through anaerobic digestion

Weijun Li, Jakob Kjøbsted Huusom, Zhimao Zhou, Yi Nie, Yajing $\mathrm{Xu}$, Xiangping Zhang

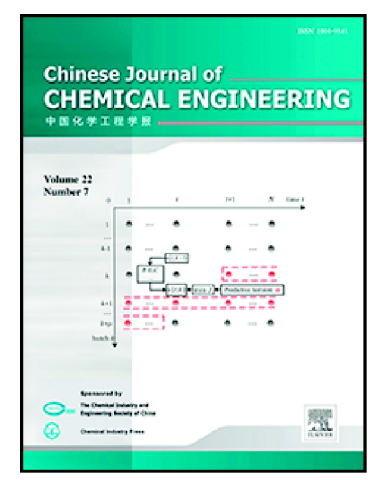

PII: S1004-9541(17)31385-X

DOI: https://doi.org/10.1016/j.cjche.2018.01.001

Reference: CJCHE 1003

To appear in:

Received date: 15 October 2017

Revised date: 22 December 2017

Accepted date: 5 January 2018

Please cite this article as: Weijun Li, Jakob Kjøbsted Huusom, Zhimao Zhou, Yi Nie, Yajing Xu, Xiangping Zhang, Multi-objective optimization of methane production system from biomass through anaerobic digestion. The address for the corresponding author was captured as affiliation for all authors. Please check if appropriate. Cjche(2018), https://doi.org/10.1016/j.cjche.2018.01.001

This is a PDF file of an unedited manuscript that has been accepted for publication. As a service to our customers we are providing this early version of the manuscript. The manuscript will undergo copyediting, typesetting, and review of the resulting proof before it is published in its final form. Please note that during the production process errors may be discovered which could affect the content, and all legal disclaimers that apply to the journal pertain. 


\section{Process Systems Engineering and Process Safety}

Multi-objective optimization of methane production system from biomass

\section{through anaerobic digestion}

Weijun $\mathrm{Li}^{\mathrm{a}}{ }^{\mathrm{a},}$, Jakob Kjøbsted Huusom ${ }^{\mathrm{c}}$, Zhimao Zhou ${ }^{\mathrm{a}}$, Yi Nie ${ }^{\mathrm{a}}$, Yajing Xu ${ }^{\mathrm{a}}$, Xiangping Zhang ${ }^{\text {a, }}{ }^{*} *$

${ }^{a}$ Beijing Key Laboratory of Ionic Liquids Clean Process, State Key Laboratory of Multiphase Complex Systems, Institute of Process Engineering, Chinese Academy of Sciences, Beijing, 100190, China.

${ }^{\mathrm{b}}$ Sino-Danish Center for Education and Research, University of Chinese Academy of Sciences, Beijing, 100049, China

${ }^{\mathrm{c}}$ Department of Chemical \& Biochemical Engineering, Technical University of Denmark, DK 2800 Kgs. Lyngby, Denmark

Email: xpzhang@ipe.ac.cn

Abstract: This work addressed the multi-objective optimization of a biogas production system considering both environmental and economic criteria. A mixed integer non-linear programming (MINLP) model was established and solved with non-dominated sorting genetic algorithm II, from which the Pareto fronts, the optimal technology combinations and operation conditions were obtained and analyzed. It's found that the system is feasible in both environmental and economic considerations after optimization. The most expensive processing section is decarbonization; the most expensive equipment is anaerobic digester; the most power-consuming processing section is digestion, followed by decarbonization and waste management. The positive green degree value on the process is attributed to processing section of digestion and waste management. 3:1 chicken feces and corn straw, solar energy, pressure swing adsorption and 3:1 chicken feces and rice straw, solar energy, pressure 
swing adsorption are turned out to be two robust technology combinations under different prices of methane and electricity by sensitivity analysis. The optimization results provide support for optimal design and operation of biogas production system considering environmental and economic objectives.

Keywords: Biogas production system; MINLP; Multi-objective optimization; non-dominated sorting genetic algorithm II ; Green degree value

\section{Abbreviations}

$\begin{array}{ll}\text { BRI } & \text { briquette } \\ \text { CHO } & \text { chop } \\ \text { DGR } & \text { digester } \\ \text { SC } & \text { solar collector } \\ \text { BB } & \text { biomass boiler }\end{array}$

AGT agitator

PM1 pump1

PM2 pump2

PM3 pump3

DES desulfurization

DEH dehumidification

ADS adsorber

DES desorber

CP1 compressor1

CP2 compressor2 


$\begin{array}{ll}\text { SCP } & \text { screw press } \\ \text { SLP } & \text { slurry pool } \\ \text { MBR } & \text { Membranes } \\ \text { SF } & \text { solid filter } \\ \text { DRY } & \text { Dryer } \\ \text { CT } & \text { collection \& transportation } \\ \text { PRE } & \text { Pretreatment } \\ \text { DGN } & \text { Digestion } \\ \text { DEC } & \text { Decarbonization } \\ \text { WM } & \text { waste management }\end{array}$

\section{Introduction}

Due to the depletion of fossil fuel and the environmental problems associated with fossil energy, considerable effort has been made to search for alternative energy [1-2]. Biogas produced via anaerobic digestion of livestock and crop straw has attracted worldwide interest as it is clean and renewable energy $[1,3]$. The produced biogas is generally utilized for the production of electricity, heat, vehicle fuel [4] and natural gas substitute after purification, and the digestate byproduct can be employed as fertilizer after treatment. A typical biogas production system includes the processing section of biomass collection and transportation, pretreatment, anaerobic digestion, biogas cleaning and decarbonization, and waste management. In addition, there are a variety of options for feedstocks, digestion heat supply technologies and biogas decarbonization technologies. Thus, it's difficult to obtain the optimal flowsheet and section combination for a biogas production system only by simple calculation and empirical analysis. 
Considerable efforts have been made to evaluate and optimize the individual processing sections of a biogas production system. For example, Yu et al. [5,6] improved a site selection and biomass delivery model, and make it suitable for many types of biomass and road delivery. Singh et al. [7] developed a mathematical model for collecting and transporting biomass from fields to the power plant. The model was used to calculate the unit transportation cost, and found that the unit cost decreases as the transportation distance increases. Ariunbaatar et al. [8] compared factors like efficiency, environmental sustainability, capital and operational costs of different pretreatment pathways, and found that the process with thermal pretreatment at low temperature with two stages digestion presents the best economic performance. Mendes et al. [9] used ADM1 model to investigate the variation of biogas yield and biogas composition with changing digestion time. Wu et al. [10] established two-column six-step pressure swing adsorption simulation model for biogas decarbonization. It was found that the processes with MOF-508b and CMS-3K as adsorbents can decrease the energy consumption by $56 \%$ and $50 \%$, respectively, compared with the Zeolite $13 \mathrm{X}$ absorbent. Rehl et al. [11] conducted Life Cycle Assessment (LCA) to compare the energy efficiency and environmental impact of different biogas digestate treatment alternatives. The belt dryer is turned out to be the option with highest primary energy demand, Global Warming Potential (GWP) and acidification potential (AP) among the compared options. The solar dryer has the lowest environmental impact.

Furthermore, for comprehensive assessment of the biogas production system, $\mathrm{Wu}$ et al. [12] established energy models for each processing section and evaluated the energy efficiency of the system in 32 scenarios (2 digestion technologies alternatives, 4 decarbonization technology alternatives, 2 heat supply methods, and 2 waste heat 
recovery options). In addition, they conducted energetic-environmental-economic assessment of a typical biogas production system with three utilization pathways $(\mathrm{CPH}$, bio-methane and fuel cell) [13].

The literature work focused either on the modelling and optimization of individual processing sections, or on the assessments of the biogas production system. However, systematic optimization of the whole system considering multi indicators like economic performance and environmental impact which has a great significance to both future research and industrial applications, has not been reported.

The aim of this study is to establish a superstructure for a typical biogas production system considering nine kinds of common feedstock materials, three kinds of common heat supply technologies and four kinds of promising decarbonization technologies. Following this, the biogas production system is optimized with respect to the criteria of economic and environmental performance, and solved by employing non-dominated sorting genetic algorithm (NSGA II ) [14]. Sensitivity analysis of methane and electricity price as well as plant scales, are performed and discussed.

\section{Methodology}

\subsection{System description}

The benchmark data of this work is based on the Nanjing University of Technology's biogas demonstration project, which have a biogas production of 500 $\mathrm{m}^{3}$ per day. The studied biogas production system is present in Figure 1, which consists of the following processing sections: Biomass collection and transportation, Pretreatment (chopping and briquetting), Co-digestion, Desulphurization, Dehumidification, Decarburization (PWS, ILs, PSA, MEA), Waste management (solid-liquid separation, drying, slurry concentration). 


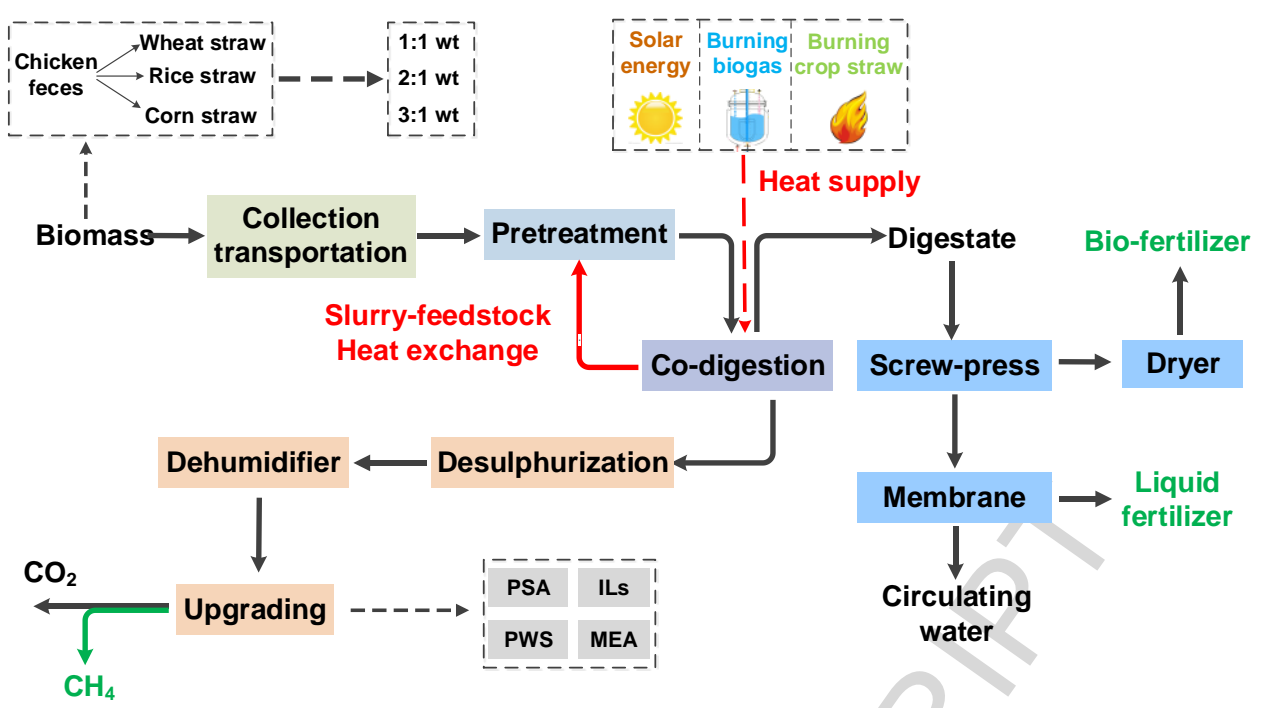

Figure 1. Biogas production and upgrading system

The mass flowrate of the feedstock (chicken feces mixes with crop straw and fresh water) is fixed at 13.6 ton/day. The total solid content (TS) in the feedstock is specified as $10 \%$. The digestate slurry outlet from digester with higher temperature is used to pre-heat the biomass feedstock by a heat exchanger. The products from the whole system are 20 bar methane, solid fertilizer and liquid fertilizer. For PWS process, the $\mathrm{CO}_{2}$ is emitted to the atmosphere directly; for other decarbonization processes, the resulting pure $\mathrm{CO}_{2}$ is treated as product. The circulating water is used to prepare digestion feedstock. The detailed description of each sections are conducted in following sections, where the models of energy consumption, economic performance and biogas yield are included and explained, as part of the objective functions.

\subsection{Models}

\subsubsection{Collection and transportation}

The demonstration project is built in the livestock farm, so only the cost and energy consumption for collecting and transporting crop straw is considered. Wu et al. [12] developed an energy consumption model Eq. (1) for the process considering a circle collection area and a tortuosity factor to validate the straight line distance. 


$$
E_{c \& t}=F C_{b} \cdot F H V \cdot \tau\left[\frac{2}{3} Q^{1.5}(\pi \rho)^{-0.5}+\left(Q+m_{c a r}\right) \cdot s\right] / V_{C H 4}
$$

where $E_{c \& t}$ is the specific energy consumption for collection and transportation section, in $\mathrm{MJ}_{\mathrm{th}} / \mathrm{Nm}^{3} \mathrm{CH}_{4}$, where the subscript $t h$ indicates thermal energy; $F C_{b}$ is the specific fuel consumption, in $\mathrm{L}$ fuel/(km ton); $F H V$ is the lower heating value of the liquid fuel, in $\mathrm{MJ}_{\mathrm{th}} / \mathrm{L} ; \tau$ is the tortuosity factor, equal to $1.5 ; \rho$ is the distribution density of crop straw, in ton $/ \mathrm{km}^{2} ; m_{\text {car }}$ is the mass of transport truck, in ton; $s$ is the distance from livestock farm to crop straw collection site, in $\mathrm{km} ; Q$ is the collection rate of crop straw, in ton/day; $V_{C H 4}$ is the volume flowrate of methane, in $\mathrm{Nm}^{3} /$ day.

The cost of this section is only fuel cost from transportation by assuming no commercial value of chicken feces and crop straws. Then the cost is calculated by Eq. (2)

$$
C_{c \& t}=\tau \cdot P_{t} \cdot\left[\frac{2}{3} Q^{1.5}(\pi \rho)^{-0.5}+(Q+m) \cdot s\right]
$$

where $C_{c \& t}$ is the cost of collection and transportation section, in $\$ /$ day; $P_{t}$ is the specific transportation cost, in $\$ /($ ton $\mathrm{km})$.

The mass flowrates of feedstock materials are calculated by Eqs. (3) - (4)

$$
\begin{gathered}
Q_{\text {chickenfeces }}=n Q_{i, \text { straw }} \\
Q_{\text {chickenfeces }} T S_{\text {chickenfeces }}+Q_{i, \text { straw }} T S_{i, \text { starw }}=1.36
\end{gathered}
$$

where $Q_{\text {chickenfeces }}$ is the mass flowrate of chicken feces in feedstock, in ton/day; $Q_{i, \text { straw }}$ is the mass flowrate of $i$ straw in feedstock, in ton/day; $n$ is the mass ratio of chicken feces and crop straw; $T S_{\text {chickenfeces }}$ and $T S_{i, \text { straw }}$ are the solid content in chicken feces and $i$ straw, $i=$ wheat, corn, rice.

\subsubsection{Pretreatment}

Machines for chopping and briquetting are employed for the pretreatment of the crop straw to enhance its decomposition and hence the biogas yield.

Bitra et al. [15] presented the energy consumption model of the chopping process 


$$
\mathrm{E}_{\text {chop }}=\left(54.02-0.05 d-10.45 Q_{\text {straw }}-0.16 d Q_{\text {straw }}+0.02 d^{2}+1.12 Q_{\text {straw }}^{2}\right) \cdot Q_{\text {straw }} \cdot 3.6 /\left(V_{C H_{4}} \cdot \eta_{H T E}\right)
$$

Mani et al. [16] presented the energy consumption model of the briquetting process

$$
\mathrm{E}_{\text {briq }}=\left(4.76+1.48 P_{B}-0.19 \mathrm{M}+0.032 \mathrm{P}_{\mathrm{B}} \mathrm{M}\right) \cdot \mathrm{Q}_{\text {straw }} / 0.39 / V_{C H_{4}}
$$

Total energy consumption was calculated by using Eq. (7)

$$
\mathrm{E}_{\text {pre }}=\mathrm{E}_{\text {chop }}+\mathrm{E}_{\text {briq }}
$$

where $E_{\text {chop }}, E_{\text {briq }}$ and $E_{\text {pre }}$ are the specific energy consumption of chopping, briquetting, pretreatment processes, in $\mathrm{MJ}_{\mathrm{th}} / \mathrm{Nm}^{3} \mathrm{CH}_{4}$, respectively. $d$ is the particle size after chopping, in mm; $Q_{\text {straw }}$ is the straw collection rate, in ton/day; $\eta_{H T E}$ is conversion efficiency of thermal energy to electric energy, 0.39 [17]; $P_{B}$ is the briquetting pressure, in $\mathrm{MPa} ; M$ is moisture content of crop straw.

The equipment involved in this section are machines of chopping and briquetting, with fixed cost of $3000 \$$ for each one. The variable cost is the power prices, calculated by Eq. (8).

$$
E P_{\text {pre }}=E P_{\text {pre }} \cdot V_{\mathrm{CH}_{4}} / 3.6 \cdot \eta_{\mathrm{HTE}} \cdot P_{\text {ele }}
$$

where $E P_{\text {pre }}$ is the electricity cost per day, in $\$ /$ day; $P_{\text {ele }}$ is the electricity price, in $\$ / \mathrm{kWh}$.

\subsubsection{Co-Digestion}

Co-digestion is the simultaneous digestion of a mixture of two or more substrates, with technological, ecological and economic advantages [18]. This project applied a mixture of chicken feces, crop straw (wheat straw, corn straw, rice straw) and fresh water as digestion feedstock. The biogas yield strongly depends on the types and composition of feedstock, the digestion temperature $(T)$, and the residence time $(t)$. The empirical equation of biogas yield is reported by Ou-yan et al. [19], as a function of $T, t$ and substrate composition.

The energy consumption of an anaerobic digestion section mainly consists of four 
parts: heat for heating the fresh feedstock $\left(E_{\text {heating }}\right)$, heat loss of the digester due to convection heat loss $\left(E_{\text {loss }}\right)$, power for mechanical agitation $\left(E_{a g i}\right)$ and the power for pumping the feedstock $\left(E_{\text {pump }}\right)$. The models are presented in Eqs. (9) - (14). The power of the pump is necessary to estimate its investment cost and is calculated by Eq. (13) $[20]$.

$$
\begin{gathered}
E_{\text {heating }}=\left(T-T_{\text {amb }}\right) \cdot C_{p m} \cdot Q_{f} / V_{C H_{4}} \\
E_{\text {loss }}=24 \cdot 3.6 \cdot\left(T-T_{\text {amb }}\right) / 1000 \cdot\left(\frac{S_{\text {side }}+S_{\text {top }}}{\left.\frac{\delta_{D}}{\lambda_{D}}+\frac{\delta_{\text {ins }}}{\lambda_{\text {ins }}}+\frac{1}{\alpha}+\frac{S_{\text {bot }}}{\frac{\delta_{D}}{\lambda_{D}}+\frac{\delta_{\text {ins }}}{\lambda_{\text {ins }}}}\right) / V_{C H_{4}}}\right. \\
W_{\text {agi }}=6 t / 24.265 \\
E_{\text {agi }}=86.4 W_{\text {agi }} / V_{C H_{4}} / \eta_{H T E} \\
W_{\text {pump }}=u\left(P_{2}-P_{1}\right) /\left(\rho_{f} \eta_{p} \eta_{m}\right) / 1000 \\
E_{\text {pump }}=24 \cdot 3.6 \cdot W_{\text {pump }} / V_{C H_{4}}
\end{gathered}
$$

where $E_{\text {heating }}, E_{\text {loss }}, E_{\text {agi }}, E_{\text {pump }}$ are the specific energy consumption by heating substrate, compensating heat loss, agitation and pumping, in $\mathrm{MJ}_{\mathrm{th}} / \mathrm{Nm}^{3} \mathrm{CH}_{4}$, respectively; $W_{a g i}$ and $W_{\text {pump }}$ are the power of agitator and pump, in $\mathrm{kW}$, respectively. $t$ is the digestion time, day; $T$ and $T_{a m b}$ are the digestion and ambient temperature, in ${ }^{\circ} \mathrm{C}$, respectively. $C_{p m}$ is the specific heat capacity of substrate in digester, assuming 4.2 $\mathrm{kJ} /(\mathrm{kg} \mathrm{K})$, because it has similar property with water. $Q_{f}$ is the mass flowrate of the feedstock, in ton/day; $S_{\text {top }}, S_{\text {bot }}, S_{\text {side }}$ are the top, bottom and side areas of the digester, in $\mathrm{m}^{2}$, respectively, which can be easily calculated by assuming that the diameter equals to height; $\delta_{\text {ins }}$ and $\delta_{D}$ are the thickness of the insulation layer and the digester, in $\mathrm{m}$, respectively. $\lambda_{\text {ins }}$ and $\lambda_{D}$ are the coefficient of thermal conductivity of the insulation layer and the digester, in $\mathrm{W} /(\mathrm{m} \mathrm{K})$, respectively. $\alpha$ is the heat transfer coefficient, in $\mathrm{W} /\left(\mathrm{m}^{2} \mathrm{~K}\right) ; \rho_{f}$ is the feedstock density, in $\mathrm{kg} / \mathrm{m}^{3} ; P_{1}$ and $P_{2}$ are the pressure before and after pumping, in bar, respectively. $\eta_{p}$ and $\eta_{m}$ are the efficiencies 
of pump (0.5) and motor (0.9), respectively.

The equipment involved in the digestion section includes digester, pump, agitator and heat supply equipment. The equipment for heat supply includes three alternatives, i.e., solar collector, biogas boiler and biomass boiler. The price of digester and insulation is $100 \$ / \mathrm{m}^{3}[13]$, the price of agitator is estimated according to its power, around $700 \$ / \mathrm{kW}$ [21]. The prices of biogas boiler and biomass boiler are $4200 \$$. The cost of solar collector is $150 \$ / \mathrm{m}^{2}$ [22]. The investment cost (IC) of pump is estimated according to the bare module costs method reported by Biegle et al. [20], shown in Eqs. (15) - (16)

$$
\begin{gathered}
\mathrm{BC}=\mathrm{C}_{0}\left(\mathrm{~S} / \mathrm{S}_{0}\right)^{\alpha} \\
I C=U F \cdot B C(M P F+M F-1)
\end{gathered}
$$

where $B C$ is the base cost, and $I C$ is the investment cost and $U F$ is an update factor for current price, 4.91 [23]; $C_{0}$ is the reference cost, in $\$ ; S_{0}$ is the reference characteristic values of equipment like power and heat duty; $S$ is the characteristic values of equipment; $M P F$ and $M F$ are material and pressure correction factor and module cost.

The area of solar collector is calculated according to Eq. (17)

$$
A=\left(E_{\text {heating }}+E_{\text {loss }}\right) /\left(I \cdot \eta_{j} \cdot\left(1-\eta_{s}\right)\right)
$$

where $A$ is the area of solar collector, in $\mathrm{m}^{2} ; I$ is intensity of solar radiation per day, in $\mathrm{kJ} /\left(\mathrm{m}^{2}\right.$ day $) ; \eta_{j}$ is the efficiency of solar collector, $0.55 ; \eta_{s}$ is the heat loss rate of pipeline and water storage tank, 0.1 .

The power price is calculated by Eq. (18)

$$
E P_{\text {ferm }}=E_{\text {ferm }} \cdot V_{C H_{4}} / 3.6 \cdot \eta_{H T E} \cdot P_{\text {ele }}
$$

\subsubsection{Desulfurization and Dehumidification}

Biogas mainly consists of $\mathrm{CO}_{2}$ and $\mathrm{CH}_{4}$ and small amount of water vapor and trace amount of $\mathrm{H}_{2} \mathrm{~S}$. Generally, the $\mathrm{H}_{2} \mathrm{~S}$ content in raw biogas is in the range of 200 
to 2000 ppmv. The desulfurization method and setup as well as plant performance and economic factors are reported by Krischan et al. [24]. The water vapor in biogas ranges from $5 \%$ to $10 \%$, depending on the temperature [25], assuming $7 \%$ in this study. Refrigeration dryer is employed for dehumidification. Its price and power is $4500 \$$ and $3 \mathrm{~kW}$, respectively.

\subsubsection{Decarburization}

The technology options for decarburization section include pressured water scrubbing (PSW), ionic liquid scrubbing (ILs), monoethanolamine scrubbing (MEA) and pressure swing adsorption (PSA). The modelling of these upgrading technologies is our previous work $[10,26,27]$. For the former three technologies, $\mathrm{L}_{16}\left(4^{3}\right)$ orthogonal test is designed to obtain empirical models for key parameters, i.e. gas liquid ratios, the amount of circulating gas, diameter of columns and energy consumption.

The empirical formulas are used to determine the gas flowrate, circulating solvent flowrate, which are necessary to calculate the size and power of pump, compressor, blower, flash, and the investment of solvents. For PWS and ILs processes, the gas flowrate into the absorber is determined by Eq. (19); for MEA process, it's determined by Eq. (20). The circulating solvent flowrate in absorber is calculated by Eq. (21). For MEA process, the biogas flowrate in to the absorber is calculated by Eq. (22)

$$
\begin{aligned}
& F_{\text {feedgas }}=\gamma \times V_{\text {biogas }} \\
& F_{\text {feedgas }}=V_{\text {biogas }} \\
& L=F_{\text {feedgas }} /\left(g / l_{a}\right) \\
& \mathrm{F}_{\text {feedair }}=\mathrm{L} \times\left(\mathrm{g} / \mathrm{l}_{\mathrm{s}}\right)
\end{aligned}
$$

where $F_{\text {feedgas }}$ is the flowrate of gas into absorber, in $\mathrm{Nm}^{3} /$ day; $\gamma$ is the amount of circulating gas, in $\%$; $V_{\text {biogas }}$ is the flowrate of biogas, in $\mathrm{Nm}^{3} /$ day; $L$ is the flowrate of solvent, in $\mathrm{m}^{3} / \mathrm{day}$.

For PWS, ILs and MEA processes, their specific energy consumptions are 
calculated according to the empirical models. For adiabatic PSA process, the energy consumption is estimated according to Eq.(23) [28].

$$
E_{P S A}=\left(\frac{\gamma}{\gamma-1}\right) R T_{\text {feed }}\left[\left(\frac{P_{\text {high }}}{P_{\text {low }}}\right)\left(\frac{\gamma-1}{\gamma}\right)-1\right] \cdot \frac{F}{1000 \eta} \cdot \frac{3.6}{V_{C H_{4}}} / \eta_{H T E}
$$

where $F$ is the flowrate of gas stream, in mol/s; $P_{\text {high }}$ and $P_{\text {low }}$ are the adsorption pressure and the desorption pressure, in bar, respectively. $T_{\text {feed }}$ is the temperature of gas stream, in ${ }^{\circ} \mathrm{C} ; \gamma=C_{p} / C_{v}$, which assumes a value of $1.31 ; \eta$ is the mechanical efficiency, 0.8 in this study.

After decarbonization, a multistage pump is employed to compress the $\mathrm{CH}_{4}$ to 20 bar to meet the natural gas grid requirement. The equipment involved in each processes are summarized in Table 1 .

Table 1. Equipment involved in different processes

\begin{tabular}{ll}
\hline Process & Equipment \\
\hline & Absorber, Desorber \\
\cline { 2 - 2 } PWS & Compressor $\times 2$ \\
\cline { 2 - 2 } & Blower \\
\cline { 2 - 2 } & Flash tank \\
\hline ILs & Absorber \\
\hline & Compressor $\times 2$, Vacuum pump \\
\hline & Pump \\
\hline & Flash tank $\times 2$ \\
\hline
\end{tabular}




\begin{tabular}{ll} 
& Expander \\
\hline \multirow{2}{*}{ MEA } & Absorber, Desorber \\
\cline { 2 - 2 } & Blower \\
\cline { 2 - 2 } & Pump $\times 2$ \\
\cline { 2 - 2 } PSA & Heat exchanger, Condenser, Reboiler \\
\hline Recompression & Adsorption column $\times 2$ \\
\cline { 2 - 2 } & Compressor $\times 2$ \\
\hline
\end{tabular}

The investment costs of pump, vacuum pump, compressor, blower, column, heat exchanger, reboiler and condenser (treated as heat exchangers), and flash are calculated by Eqs. (15), (16), (24) [20].

$$
B C=C_{0}\left(L / L_{0}\right)^{\alpha}\left(D / D_{0}\right)^{\beta}
$$

where $L_{0}, D_{0}$ are the reference characteristic values of equipment like size, power and heat duty; $L, D$ are the characteristic values of equipment.

The purchase cost of water, MEA solvent, $[\mathrm{Bmim}]\left[\mathrm{Tf}_{2} \mathrm{~N}\right]$ solvent and CMS-3K adsorbent is $0.46 \$ /$ ton, $1500 \$ /$ ton, $224900 \$ /$ ton and $15000 \$ /$ ton, respectively.

\subsubsection{Waste management}

In this study, the digestate is firstly sent to a screw-press for solid-liquid separation. Then solid fraction of digestate with $65 \%$ water content goes to a dryer machine to get solid bio-fertilizer. The liquid fraction goes to hybrid membrane technology for recovery of liquid fertilizer and industrial water [29]. The sand filter firstly traps the suspended material and bacterial. Then the permeate get through microfiltration membrane, ultrafiltration membrane and nanofiltration membrane successively to get the concentrated liquid fertilizer and circulating water. The operation pressure of MF membrane and NF is 2 bar and 4.8 bar, respectively. Hence two pumps are employed to meet the operation pressures. Assume that after concentration, permeation fluid accounts $80 \%$ of the total slurry flowrate. The energy 
consumption for screw-press and dryer, $E_{\text {sep\&dry }}$, was established by Wu et al. [12] and shown in Eq.(25)

$$
\mathrm{E}_{\text {sep\&dry }}=\left(4.3 \times m_{\text {slurry }}+130 \times m_{\text {digestate }}\right) / V_{C H_{4}}
$$

where $m_{\text {slurry }}$ is the mass flowrate of the digestate slurry, in ton/day; $m_{\text {digestate }}$ is the mass flowrate of solid fraction of digestate, in ton/day.

The energy consumption for the two pumps and the waste management section is calculated by using Eq. (26) - (28).

$$
\begin{gathered}
W_{\text {pump }}=u\left(P_{2}-P_{1}\right) /\left(\rho_{f} \eta_{p} \eta_{m}\right) / 1000 \\
E_{\text {pump }}=24 \cdot 3.6 \cdot W_{\text {pump }} / V_{C H_{4}} \\
E_{\text {wm }}=E_{\text {sep\&dry }}+E_{\text {pump } 1}+E_{\text {pump } 2}
\end{gathered}
$$

where $E_{\text {wm }}, E_{\text {pump } 1}, E_{\text {pump } 2}$ are the specific energy consumptions of waste management section, in $\mathrm{MJ}_{\mathrm{th}} / \mathrm{Nm}^{3} \mathrm{CH}_{4} . E P_{w m}$ is the electricity price, in $\$ /$ day.

The electricity price is calculated by using Eq. (29)

$$
E P_{w m}=E_{w m} \cdot V_{C H_{4}} / 3.6 \cdot \eta_{H T E} \cdot P_{\text {ele }}
$$

The cost of sand filter, microfiltration membrane, ultrafiltration membrane, nanofiltration membrane and biogas slurry pool is $1274 \$, 600 \times 4 \$, 577 \times 4 \$, 360 \times$ 4 \$ and 6000 \$, respectively. The costs of pumps are calculated by using Eq. (15) and (16) from the previous section.

\subsection{Optimization}

\subsubsection{Objective functions}

In this study, the economic and environmental performance are evaluated using NPV method and Green degree method, respectively. The NPV of the biogas production system is calculated by Eqs. (30) - (31). The project is economically feasible if the NPV is positive [30].

$$
N P V=\sum_{t=0}^{N} \frac{C F_{t}}{(1+r)^{n}}
$$




$$
C F_{t}=-C F_{0}+\sum_{i=1}^{t} G M
$$

where $C F_{0}$ is the initial investment, $\$ ; G M$ is the gross margin per year, a constant value by assuming stable operation, $\$ ; r$ is the discount rate, which assumes a value of 0.05 .

Payback period (PB) and internal rate of return (IRR) are two important economic parameters for assessing economic feasibility of the process. They can be calculated according to Eqs. (32)-(33).

$$
\begin{gathered}
G M=C F_{0}\left[\frac{r(1+r)^{P B}}{(1+r)^{P B}-1}\right] \\
\sum_{t=0}^{n} \frac{C F_{t}}{(1+r)^{t}}=0
\end{gathered}
$$

The initial investment $\left(C F_{0}\right)$ is the total facility investment $(T F I)$, which consists of two components i.e. base plant cost $(B P C)$ and project contingency $(P C)$; the gross margin $(G M)$ is defined as the revenue of product minus the operation cost. The methodology was proposed by Hussain [31] and is shown in table 2.

Table 2. Economic and process factors for biogas project

\begin{tabular}{lcc}
\hline Category & \multicolumn{1}{c}{ Value } & Unit \\
\hline Total Facility Investment (TFI) & $F C=I C$ & $\$$ \\
Fixed Cost (FC) & $B P C=1.12 F C$ & $\$$ \\
Base plant cost (BPC) & $P C=0.2 B P C$ & $\$$ \\
Project contingency (PC) & $T F I=B P C+P C$ & $\$$ \\
Total facility investment & & \\
$(\mathrm{TFI})$ & & \\
\hline
\end{tabular}




\begin{tabular}{|c|c|c|}
\hline \multicolumn{3}{|c|}{ Operating and Maintenance Cost $(\mathrm{O \& M})$} \\
\hline Water Cost (WC) & $W C=0.46\left(Q_{\text {feedstock }}-Q_{\text {straw }}-Q_{\text {feces }}+4 / 5 \cdot Q_{\text {slurry }}\right.$ & $\$ /$ year \\
\hline Energy Cost (EC) & $\begin{aligned} E C_{\text {ele }} & =E \cdot V_{\mathrm{CH}_{4}} / 3.6 \cdot \eta_{\mathrm{HTE}} P_{\text {ele }} \\
E C_{\text {heat }} & =E C_{\text {heat }} \cdot V_{\mathrm{CH}_{4}} / 3.6 \cdot P_{\text {heat }}\end{aligned}$ & $\$ /$ year \\
\hline Labor cost (LC) & $L C=0.1 \cdot O C[32]$ & $\$ /$ year \\
\hline $\begin{array}{l}\text { Local tax and insurance } \\
\text { (LTI) }\end{array}$ & $L T I=0.01 \cdot T F I[13]$ & $\$ /$ year \\
\hline Maintenance Cost (MC) & $M C=0.04 \cdot T F I[31]$ & $\$ /$ year \\
\hline $\begin{array}{l}\text { Operating and Maintenance } \\
\text { Cost }(\mathrm{O} \& \mathrm{M})\end{array}$ & $O \& M=W C+E C_{\text {ele }}+E C_{\text {heat }}+L C+L T I+M C$ & $\$ /$ year \\
\hline Revenue of product $(\mathbf{R P})$ & $R P=0.5997 V_{C H_{4}} \cdot 333$ & \$/year \\
\hline Gross margin (GM) & $G M=R P-O \& M$ & $\$$ /year \\
\hline
\end{tabular}

Green degree $(G D)$ is a composite index proposed by Zhang et al. [33] for quantitatively assessing the environmental impact of a substance, stream or process based on nine environmental categories [33]. The Green degrees of substance, stream and process are calculated by Eqs. (34) - (39). A positive $G D$ value indicates that the process is benign to environment.

$$
\begin{gathered}
\mathrm{GD}_{i}^{s u}=-\sum_{j}^{9}\left(100 \alpha_{i, j} \varphi_{i, j}^{N}\right) \\
\varphi_{i, j}^{N}=\varphi_{i, j} / \varphi_{j}^{\max }, \varphi_{j}^{\max }=\max \left(\varphi_{i, j}\right) \\
\sum_{j=1}^{9} \alpha_{i, j}=1 \\
\mathrm{i}=1,2,3 \ldots ; \mathrm{j}=1,2,3 \ldots, 9 \\
\mathrm{GD}^{S t}=F \times \sum_{k=1}^{m} G D_{k}^{S u} x_{k} \\
\Delta G D_{j}^{S t}=\sum G D_{k}^{S t, o u t}-\sum G D_{i}^{S t, i n} \\
\Delta \mathrm{GD}^{P}=\sum G D_{i}^{\text {Energy }, \text { in }}+\sum \Delta G D_{j}^{S t}
\end{gathered}
$$

where $G D_{I}^{s u}$ is the green degree of substance $i, \mathrm{gd} / \mathrm{kg} ; G D^{S t}$ is the green degree of the stream, $\mathrm{gd} / \mathrm{day} ; G D_{i}^{\text {St,in }}$ and $G D_{k}^{\text {St,out }}$ is the green degree of input and output material stream, $\mathrm{gd} / \mathrm{day} ; \Delta G D_{j}^{S t}$ is the green degree production of the stream, $\mathrm{gd} / \mathrm{day} ; G D^{P}$ is 
the green degree of the process, $\mathrm{gd} / \mathrm{day} ; F$ is the mass flowrate, $\mathrm{kg} / \mathrm{day} ; x_{k}$ is the mass fraction of substance k; $G D_{i}^{\text {Energy,in }}$ is the green degree of the input energy, $\mathrm{gd} / \mathrm{day}$.

Based on models established above, seven important variables were chosen for our optimization problem: digestion temperature, residence time, absorption pressure, lean liquid loading, types and compositions of biomass, decarbonization technologies and heating modes of digester. They are summarized in Table 3.

The presented energy and economic model are coupled with the mass balance models for each technology in formulation of the optimization problem. Gas densities of biogas, $\mathrm{CO}_{2}$ and $\mathrm{CH}_{4}$ are $1.276 \mathrm{~kg} / \mathrm{m}^{3}, 0.717 \mathrm{~kg} / \mathrm{m}^{3}$ and $1.96 \mathrm{~kg} / \mathrm{m}^{3}$, respectively, which are necessary for mass balance.

Table 3. Variables of the optimization problem and their boundaries

\begin{tabular}{|c|c|c|c|c|c|}
\hline Property & & Variables & Variables specification & Boundary & Unit \\
\hline Global & \multirow{4}{*}{$\begin{array}{l}\text { Continuous } \\
\text { variables }\end{array}$} & $\bar{T}$ & Digestion temperature & {$[35,55]$} & ${ }^{\circ} \mathrm{C}$ \\
\hline variables & & $t$ & Residence time & {$[18.7,29.3]$} & day \\
\hline Local & & & Absorption pressure & {$[7,10]$} & bar \\
\hline variables & & & liquid loading & {$[0.13,0.28]$} & - \\
\hline \multirow{3}{*}{$\begin{array}{l}\text { Global } \\
\text { variables }\end{array}$} & \multirow{3}{*}{$\begin{array}{l}\text { Integer } \\
\text { variables }\end{array}$} & & biomass & {$[1,9]$} & - \\
\hline & & $y$ & $\begin{array}{l}\text { Biogas decarbonization } \\
\text { techniques }\end{array}$ & {$[1,4]$} & - \\
\hline & & $z$ & Heating mode of digester & {$[1,3]$} & - \\
\hline
\end{tabular}

Note that the local variables are activated only when relevant technologies are selected. The absorption pressure will be activated when ILs and PWS technologies are selected. The lean liquid loading will be activated when MEA technology is selected.

\subsubsection{Multi-objective optimization formulation}

With all these models, variables and objective functions, a mixed-integer nonlinear programming (MINLP) problem is formulated and solved with a real-coded 
non-dominated sorting genetic algorithms- II (NSGA- II ) to maximize the NPV and Green degree simultaneously. The MINLP model is coded in MATLAB. All the computational studies are performed on a workstation with an intel Xeon ${ }^{@}$ professor E5-2670 v3 2.30 GHz-CPU, and 64-GB (8×8GB) RAM. The population size is set as 1000 , and the number of generation is set as 6000 . The crossover probability of crossover $\left(P_{c}\right)$ and mutation $\left(P_{m}\right)$ are 0.9 and 0.1 , respectively.

\section{Results and Discussion}

\subsection{Optimization results}

The program is implemented 10 runs, from which the consistent Pareto-optimal solution set is obtained. The Pareto solutions are generated with respect to two objectives, shown in Figure 2. Note that the true Pareto front is difficult to obtain, hence in industrial a reference solution set is used to represent it. The Pareto curve shows the optimal trade-off designs of the biogas production system. Each Pareto point on the three curves represents the optimal design of the biogas production system with unique tradeoff between the NPV and Green degree. As shown in Figure 2, the environmental impact is positive for all the Pareto solutions, in the range of $1.23 \times 10^{5} \mathrm{gd} /$ year to $1.75 \times 10^{5} \mathrm{gd} /$ year. The NPV is positive for all the Pareto solutions, from $0.30 \times 10^{5} \$$ to $1.40 \times 10^{5} \$$. So the solutions are feasible in both environmental and economic considerations. Curve A presents highest average Green degree, but lowest average NPV. Curve C presents highest average NPV, but lowest average Green degree.

The technology combinations of these three curves are shown in Table 4. According to the simulation results listed in Table 4, 3:1 (wt $\%$ ) chicken feces and rice straw and 3:1 (wt\%) chicken feces and corn straw are demonstrated to be the optimal two feedstock among the feedstock candidates in this study. PSA is demonstrated to 
be the optimal decarbonization option. The ILs and PWS technologies have relative low energy consumption but high fixed cost. Because they are physical absorption with relative low absorption capacity, hence they have large amount of circulating solvent, resulting in large equipment sizes and high fixed cost. The advantages of lower energy consumption can not compensate their disadvantages of higher fixed cost, so they died in the evolution. The MEA process is based on chemical absorption with high absorption capacity, so it has small equipment size and fixed cost. But it has much higher energy consumption due to higher reboiler duty. And the extra electricity cost associated with energy consumption can compensate the advantages of fixed cost. So the MEA process died in the evolution. The PSA technology has relative low fixed cost, low energy consumption and it doesn't emit $\mathrm{CO}_{2}$ to the environment hence it's optimal in both economical and environmental considerations. By comparing curves A and B with C, solar energy has advantage regarding environmental feasibility while biomass boiler has advantage regarding to economic feasibility. Because the solar collector is expensive while the biomass boiler is cheap but it releases flue gases like $\mathrm{CO}_{2}, \mathrm{SO}_{2}$ and $\mathrm{NO}_{\mathrm{x}}$. Biogas to supply heat demand doesn't appear in the optimized profile hence it's demonstrated to be an un-ideal choice.

Table 4. The optimized technology combinations

\begin{tabular}{cccc}
\hline Pareto curve & Feedstock & Heat supply & $\begin{array}{r}\text { Decarbonization } \\
\text { technology }\end{array}$ \\
\hline A & $\begin{array}{c}3: 1(\mathrm{wt} \%) \text { chicken } \\
\text { feces and corn straw }\end{array}$ & Solar energy & PSA \\
& $\begin{array}{c}3: 1(\mathrm{wt} \%) \text { chicken } \\
\text { B }\end{array}$ & Solar energy & PSA
\end{tabular}




$\begin{array}{ccc}\text { C } & \text { 3:1 (wt } \%) \text { chicken } & \text { Biomass boiler }\end{array}$

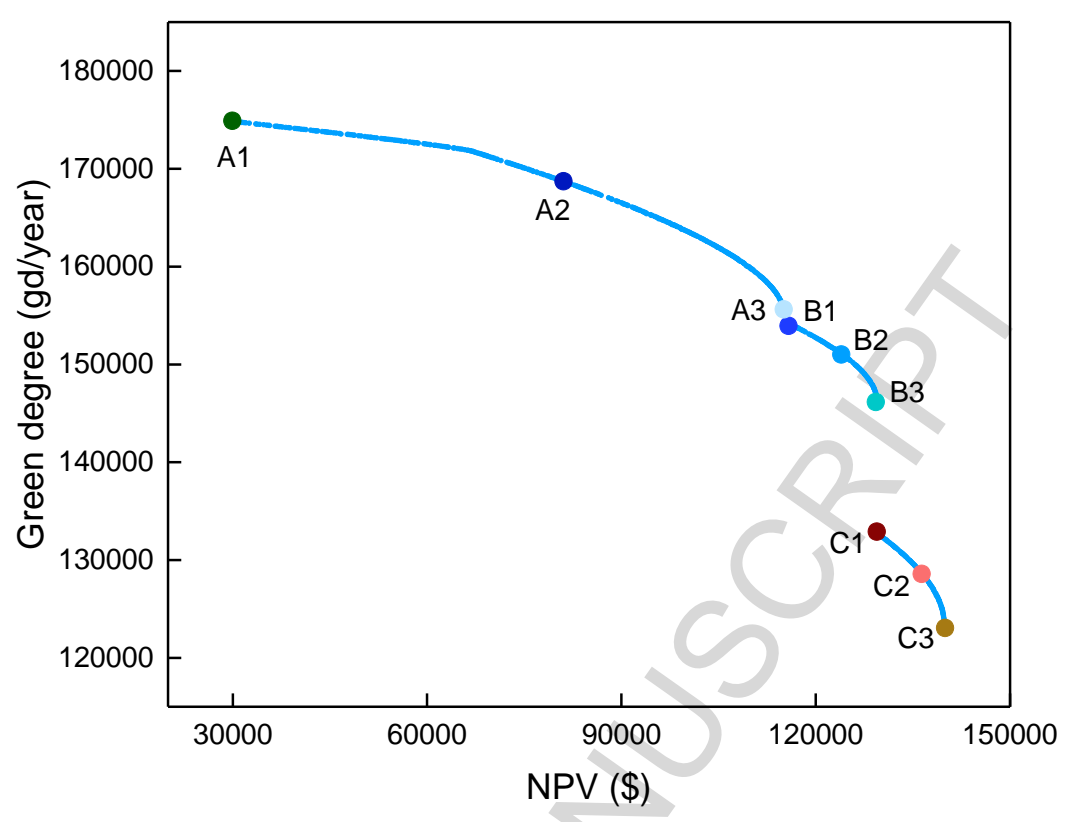

Figure 2. Pareto optimal curve

By visual inspection, the Pareto fronts in different technology combinations have similar trend. The NPV are increasing in the direction from Pareto point A1 to C3 at the expense of decreasing the Green degree value, which shows the tradeoff relations between NPV and Green degree. A1 has the highest Green degree of $174830 \mathrm{gd} / \mathrm{year}$ due to its lowest energy consumption and the use of solar collector. But it has the lowest NPV 30191 \$ due to its lowest biogas yield resulting from the lowest digestion temperature and shortest residence time. C3 has the highest NPV 139850 \$ and the lowest Green degree $123460 \mathrm{gd} /$ year.

The goal of the optimization is to maximize these two objectives simultaneously, but along the Pareto front no objective can be improved without the expense of other objectives. The region above the Pareto front is the infeasible region. 
Table. 5 The process configurations and performance of the selected Pareto points

\begin{tabular}{|c|c|c|c|c|c|c|c|c|c|c|c|}
\hline No. & $\begin{array}{c}\mathrm{T} \\
\left({ }^{\circ} \mathrm{C}\right)\end{array}$ & $\begin{array}{c}\mathrm{t} \\
\text { (day) }\end{array}$ & $\begin{array}{l}\text { NPV } \\
(\$)\end{array}$ & $\begin{array}{c}\text { GD } \\
\text { (gd/year) }\end{array}$ & $\begin{array}{c}V_{\text {biogas }} \\
\left(\mathrm{Nm}^{3} / \text { day }\right)\end{array}$ & $\begin{array}{c}\text { Energy } \\
\text { consumption } \\
\left(\mathrm{MJ}_{\mathrm{th}} / \text { day }\right)\end{array}$ & $\begin{array}{c}\text { Operation } \\
\text { cost } \\
\text { (\$/year) }\end{array}$ & $\begin{array}{c}\text { Total fixed cost } \\
\text { (\$) }\end{array}$ & $\begin{array}{l}\text { Product revenue } \\
\text { (\$) }\end{array}$ & $\begin{array}{l}\text { Payback } \\
\text { Period } \\
\text { (year) }\end{array}$ & $\begin{array}{c}\text { Internal } \\
\text { Rate } \\
\text { Return(\%) }\end{array}$ \\
\hline A1 & 40.2 & 18.7 & 30191 & 174830 & 423.0 & 5240.0 & 31849 & 212620 & 48170 & 16.8 & $4.5 \%$ \\
\hline $\mathrm{A} 2$ & 46.8 & 19.7 & 80266 & 168900 & 478.4 & 5475.7 & 33511 & 20 & 54481 & 13.6 & $6.5 \%$ \\
\hline A3 & 46.9 & 25.4 & 115140 & 155000 & 533.6 & 5974.1 & 36071 & 252300 & 60769 & 12.4 & $7.5 \%$ \\
\hline $\mathrm{B} 1$ & 35.0 & 20.8 & 115390 & 154330 & 495.5 & 5606.0 & 0 & 223860 & 56430 & 11.8 & $8.0 \%$ \\
\hline B2 & 35.3 & 22.5 & 125750 & 150180 & 512.3 & 5755.1 & 34406 & 230300 & 58338 & 11.5 & $8.3 \%$ \\
\hline B3 & 35.9 & 24.3 & 129450 & 146250 & 524.4 & 5893.2 & 35128 & 236370 & 59716 & 11.5 & $8.3 \%$ \\
\hline $\mathrm{C} 1$ & 45.6 & 23.1 & 129450 & 132760 & 515.2 & 1 & 34624 & 228330 & 58672 & 11.3 & $8.5 \%$ \\
\hline $\mathrm{C} 2$ & 46.4 & 23.9 & 135310 & 129440 & & 5860.0 & 35016 & 231340 & 59661 & 11.2 & $8.6 \%$ \\
\hline $\mathrm{C} 3$ & 48.0 & 25.4 & 139850 & 123460 & & 5977.8 & 35626 & 235870 & 60880 & 11.1 & $8.7 \%$ \\
\hline
\end{tabular}


The operation condition and system performance for selected Pareto points are shown in Table 5. The digestion temperature is distributed between $35^{\circ} \mathrm{C}$ and $48^{\circ} \mathrm{C}$ and the residence time is distributed between 18.7 day and 25.4 day. Higher digestion temperature can consume a lot of energy and decrease the biogas yield simultaneously. Longer digestion time can result in large digestion volume and large agitation energy consumption hence higher fixed cost and energy consumption.

Pareto point B1 is selected and analyzed to reveal the sections cost distribution, the cost distribution of equipment in each section, the energy distribution and the green degree distribution of the system. Figure 3 presents the equipment purchase cost distribution of Pareto point B1. The most expensive equipment is the anaerobic digester, followed by compressor 1 and compressor2 in the PSA process, and the desulfurization setup. The fixed cost distribution between processing sections is shown in Figure 4. The most expensive processing section is decarbonization, followed by digestion and waste management, respectively. Figure 5 presents the energy consumption distribution among seven processing sections. As shown in Figure 5, 28.40\% of the total energy consumption is attributed to the digestion section, which includes the energy consumption of agitation and pumping. Within the digestion section, the agitation contributes $72.70 \%$ of the energy consumption of the digestion section. $27.92 \%$ of the total energy consumption is attributed to the decarbonization section, which includes the energy consumption of compressor 1 , compressor $2.27 .79 \%$ of the energy consumption is attributed to waste management section, which includes the energy consumption of pump2, pump3 and screw press and dryer. Within the waste management section, the pump2 and pump3 contribute $22.82 \%$ and $64.55 \%$ of the energy consumption, 
respectively, and the screw press and dryer contributes $12.62 \%$. It's hence concluded that most of the energy consumption comes from the pumps; membranes with better performance and at lower working pressure needs special attention in the research and development. Figure 6 presents the $G D$ distribution between processing sections. All the processing sections except decarbonization and waste management have negative Green degree. The decarbonization section has the lowest Green degree, which indicates the worst environmental performance. The Green degree of the decarbonization section is attributed to its energy consumption, and the decarbonication has very high energy consumption share as shown in Figure 5. Note that the Green degree of energy consumption is calculated based on the environmental impact associated with the energy production. For the digestion section, on one hand, it consumes a lot of energy. On the other hand, it converts biomass waste with negative $G D$ value to crude biogas product with $G D$ of 0 and biogas digestate with less environmental impact, which has positive Green degree. Compromise of the two effects mentioned above resulted in the positive Green degree, which indicates an environmental friendly process. This processing step is the biggest contributor in terms of numerical value, hence it's key to have an environmental friendly process. For the waste management section, although it consumes a lot of energy, it converts biogas digestate into fertilizer product with $G D$ of 0 . Compromise of these two effects resulted in the positive Green degree, which indicates an environmental friendly process. For the processing sections of collection and transportation, pretreatment, desulfurization and dehumidification, their Green degree are attributed to their energy consumption. 


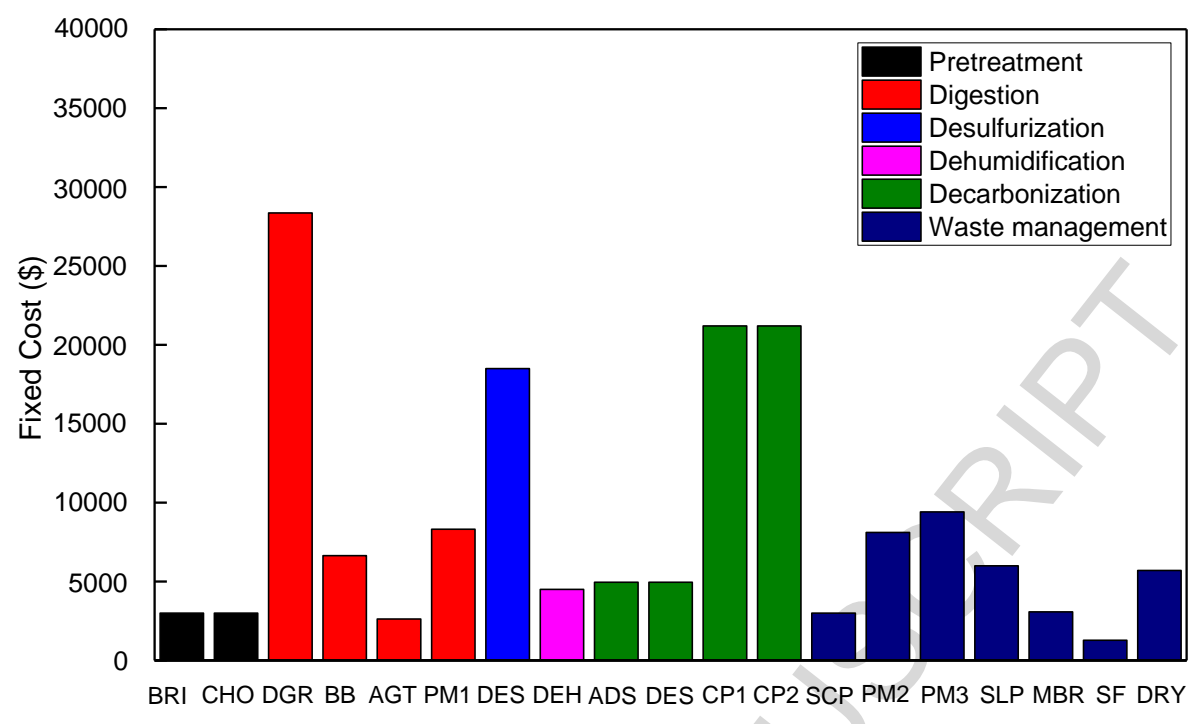

Figure 3. The equipment purchase cost distribution.

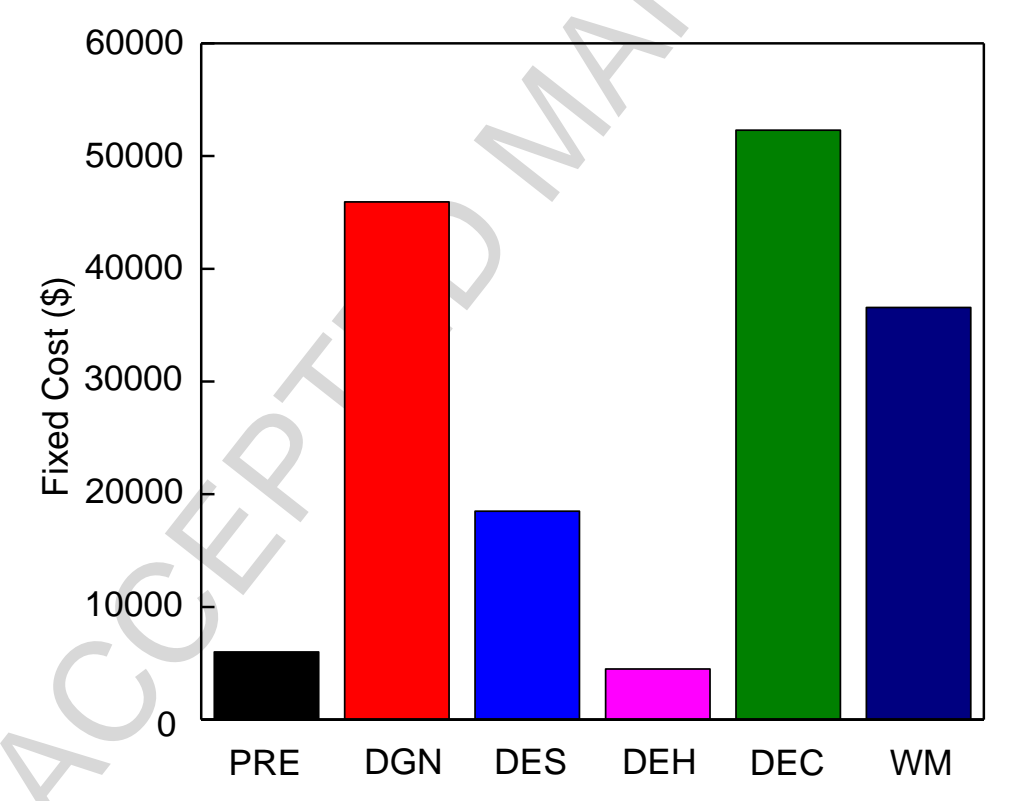

Figure 4. The processing sections purchase cost distribution. 


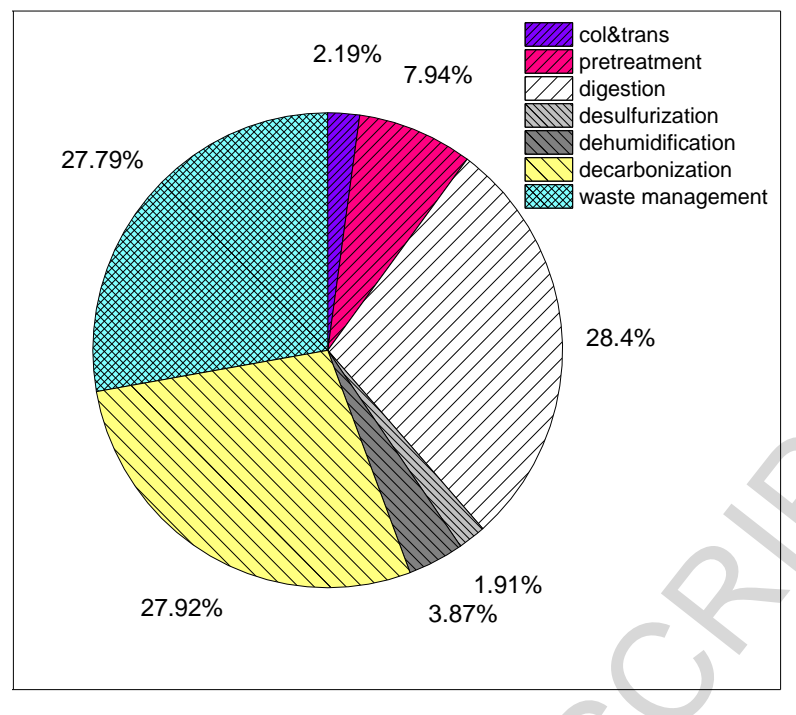

Figure 5. The energy distribution between processing sections.

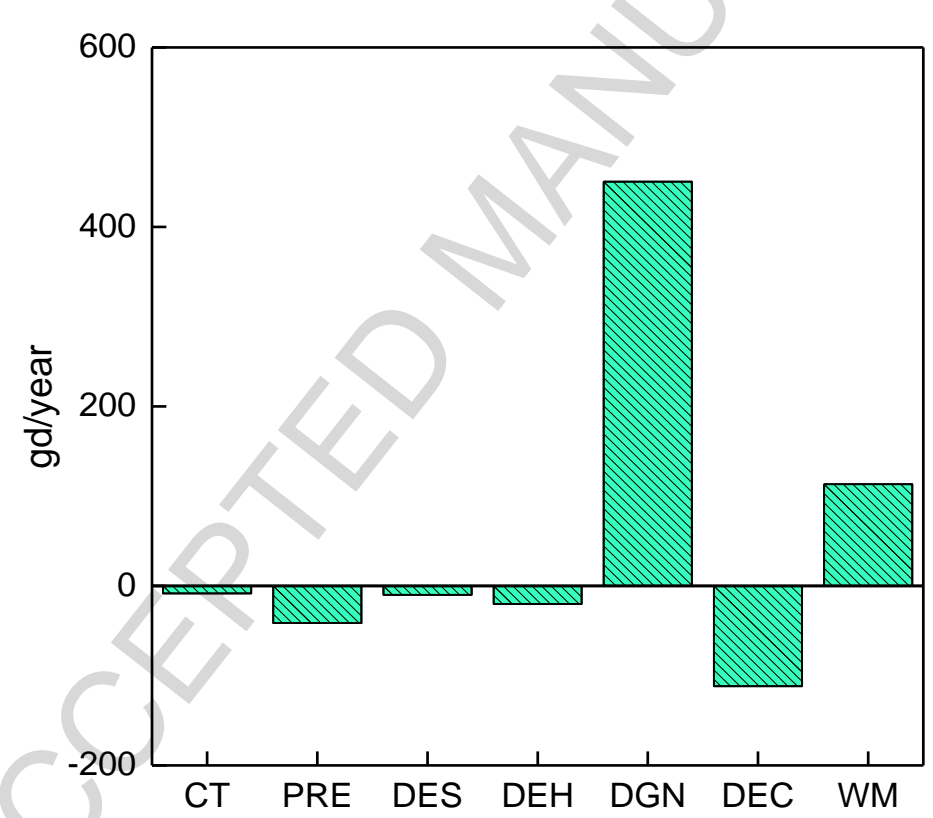

Figure 6. The green degree distribution between processing sections.

\subsection{Sensitivity analysis}

Since the prices of electricity and methane fluctuate frequently and different plant scales are required in industrial application, hence sensitivity analysis is conducted for them one by one, in order to study their effects on the optimized profiles and to study the robustness of the 
Pareto solutions. The optimized profile at different prices of electricity and methane is shown in Table 6. 
Table 6. The optimized technology combinations at different conditions

\begin{tabular}{|c|c|c|c|}
\hline $\begin{array}{l}\text { Electricity } \\
\text { price }\end{array}$ & Feedstock & Heat supply & $\begin{array}{c}\text { Decarbonization } \\
\text { technology }\end{array}$ \\
\hline \multirow{4}{*}{$0.07 \$ / \mathrm{kWh}$} & 3:1 (wt\%) chicken feces and corn straw & Solar energy & PSA \\
\hline & $3: 1(\mathrm{wt} \%)$ chicken feces and rice straw & Solar energy & PSA \\
\hline & $3: 1(\mathrm{wt} \%)$ chicken feces and rice straw & Biomass boiler & PSA \\
\hline & $3: 1(w t \%)$ chicken feces and corn straw & Biomass boiler & PSA \\
\hline \multirow{3}{*}{$0.08 \$ / \mathrm{kWh}$} & $3: 1(w t \%)$ chicken feces and corn straw & Solar energy & PSA \\
\hline & $3: 1(w t \%)$ chicken feces and rice straw & Solar energy & PSA \\
\hline & $3: 1(w t \%)$ chicken feces and corn straw & Biomass boiler & PSA \\
\hline \multirow{3}{*}{$0.09 \$ / \mathrm{kWh}$} & 3:1 (wt\%) chicken feces and corn straw & Solar energy & PSA \\
\hline & $3: 1(\mathrm{wt} \%)$ chicken feces and rice straw & Solar energy & PSA \\
\hline & $3: 1(\mathrm{wt} \%)$ chicken feces and rice straw & Biomass boiler & PSA \\
\hline Methane price & Feedstock & Heat supply & $\begin{array}{c}\text { Decarbonization } \\
\text { technology }\end{array}$ \\
\hline \multirow{3}{*}{$0.55 \$ / \mathrm{Nm}^{3}$} & 3:1 (wt\%) chicken feces and corn straw & Solar energy & PSA \\
\hline & $3: 1(w t \%)$ chicken feces and rice straw & Solar energy & PSA \\
\hline & $3: 1(\mathrm{wt} \%)$ chicken feces and rice straw & Biomass boiler & PSA \\
\hline \multirow{3}{*}{$0.57 \$ / \mathrm{Nm}^{3}$} & $3: 1(w t \%)$ chicken feces and corn straw & Solar energy & PSA \\
\hline & $3: 1(w t \%)$ chicken feces and rice straw & Solar energy & PSA \\
\hline & $3: 1(w t \%)$ chicken feces and corn straw & Biomass boiler & PSA \\
\hline \multirow{3}{*}{$0.59 \$ / \mathrm{Nm}^{3}$} & $3: 1(w t \%)$ chicken feces and corn straw & Solar energy & PSA \\
\hline & $3: 1(\mathrm{wt} \%)$ chicken feces and rice straw & Solar energy & PSA \\
\hline & $3: 1(\mathrm{wt} \%)$ chicken feces and rice straw & Biomass boiler & PSA \\
\hline Plant scale & $\mathrm{k}$ & Heat supply & $\begin{array}{c}\text { Decarbonization } \\
\text { technology }\end{array}$ \\
\hline \multirow{3}{*}{$500 \mathrm{Nm}^{3} /$ day } & $3: 1(\mathrm{wt} \%)$ chicken feces and corn straw & Solar energy & PSA \\
\hline & $3: 1(w t \%)$ chicken feces and rice straw & Solar energy & PSA \\
\hline & 3:1 (wt $\%$ ) chicken feces and corn straw & Biomass boiler & PSA \\
\hline \multirow{3}{*}{$1000 \mathrm{Nm}^{3} /$ day } & $3: 1(\mathrm{wt} \%)$ chicken feces and corn straw & Solar energy & PSA \\
\hline & $3: 1(\mathrm{wt} \%)$ chicken feces and rice straw & Solar energy & PSA \\
\hline & $3: 1(w t \%)$ chicken feces and corn straw & Biomass boiler & PSA \\
\hline \multirow{3}{*}{$2000 \mathrm{Nm}^{3} /$ day } & 3:1 (wt\%) chicken feces and corn straw & Solar energy & PSA \\
\hline & 3:1 (wt $\%)$ chicken feces and rice straw & Solar energy & PSA \\
\hline & 3:1 (wt \%) chicken feces and corn straw & Biomass boiler & PSA \\
\hline
\end{tabular}


The electricity price can affect the two objective functions by affecting the energy consumption of the system hence to affect its methane yield and operating cost. The methane price can affect the objective functions by affecting the methane yield. As a result, new Pareto solutions including technology combinations and operation conditions are obtained at different electricity price and methane price, as shown in table 6. It's interesting that some technology combinations are included in all the optimized profiles, i.e. $3: 1$ chicken feces and corn straw, solar energy, PSA and 3:1 chicken feces and rice straw, solar energy, PSA, which indicates robust technology combinations. It is also found that the plant scale has no effect on the optimized technology combinations. Consequently, these technology combinations can be safely extended to other scales.

\section{Conclusions}

Pareto fronts and solutions were obtained and analyzed for the biogas production system. The results indicate an environmental friendly and economically feasible process and can provide strategy for design and operation of the biogas production system. It's found that the most expensive processing section is decarbonization; the most expensive equipment is anaerobic digester; the most power-consuming processing section is digestion, followed by decarbonization and waste management. The positive green degree value on the process is attributed to section of digestion and waste management. 3:1 chicken feces and corn straw, solar energy, PSA and 3:1 chicken feces and rice straw, solar energy, PSA are turned out to be two robust technology combinations under different prices of methane and electricity by sensitivity analysis. 


\section{Acknowledgments}

This work was supported by the National Natural Science Fund for Distinguished Young Scholars (21425625), the National Basic Research Program of China (2013CB733506, 2015CB251403), the National Natural Science Foundation of China (U1610222), and the Beijing hundreds of leading talents training project of science and technology (Z171100001117154).

\section{References}

[1] A. M. Khan, N. Fatima, Biodiesel synthesis via metal oxides and metal chlorides catalysis from marine alga Melanothamnus afaqhusainii, Chinese J. Chem. Eng. 24(3) (2016) 388-393. [2] F. R. Abdeen, M. Mel, M. S. Jami, S. I. Ihsan, A. F. Ismail, A review of chemical absorption of carbon dioxide for biogas upgrading, Chinese J. Chem. Eng. 24(6) (2016) 693-702.

[3] F. Sgroi, A. M. Di-Trapani, M. Fodera, R. Testa, S. Tudisca, Economic performance of biogas plants using giant reed silage biomass feedstock, Ecol. Eng. 81 (2015) 481-487.

[4] C. A. G. And, A. E. Rodrigues, Layered Vacuum Pressure-Swing Adsorption for Biogas Upgrading, Ind. Eng. Chem. Res. 46(23) (2007) 7844-7848.

[5] H. Yu, Q. Wang, K. E. Ileleji, C. Yu, Z. Luo, K. Cen, J. Gore, Design and analysis of geographic distribution of biomass power plant and satellite storages in China. Part 1: Straight-line delivery, Biomass Bioenergy 46 (2012) 773-784.

[6] H. Yu, Q. Wang, K. E. Ileleji, C. Yu, Z. Luo, K. Cen, J. Gore, Design and analysis of geographic distribution of biomass power plant and satellite storages in China. Part 2: Road delivery, Biomass Bioenergy 46 (2012) 785-792.

[7] J. Singh, B. S. Panesar, S. K. Sharma, A mathematical model for transporting the biomass to biomass based power plant, Biomass Bioenergy 34(4) (2010) 483-488.

[8] J. Ariunbaatar, A. Panico, G. Esposito, F. Pirozzi, P. N. L. Lens, Pretreatment methods to enhance anaerobic digestion of organic solid waste, Appl. Energy 123 (2014) 143-156.

[9] C. Mendes, K. Esquerre, L. M. Queiroz, Application of Anaerobic Digestion Model No. 1 for simulating anaerobic mesophilic sludge digestion, Waste Manage. 35 (2015) 89-95. 
[10] B. Wu, X. Zhang, Y. Xu, D. Bao, S. Zhang, Assessment of the energy consumption of the biogas upgrading process with pressure swing adsorption using novel adsorbents, J. Clean Prod. 101 (2015) 251-261.

[11] T. Rehl, J. Mueller, Life cycle assessment of biogas digestate processing technologies, Resour. Conserv. Recy. 56(1) (2011) 92-104.

[12] B. Wu, X. Zhang, D. Bao, Y. Xu, S. Zhang, L. Deng, Biomethane production system: Energetic analysis of various scenarios, Bioresour. Technol. 206 (2016) 155-163.

[13] B. Wu, X. Zhang, D. Shang, D. Bao, S. Zhang, T. Zheng, Energetic-environmental-economic assessment of the biogas system with three utilization pathways: Combined heat and power, biomethane and fuel cell, Bioresour. Technol. 214 (2016) 722-728.

[14] K. Deb, A. Pratap, S. Agarwal, T. Meyarivan, A fast and elitist multiobjective genetic algorithm: NSGA-II, Ieee T. Evolut. Comput. 6(2) (2002) 182-197.

[15] V. S. P. Bitra, A. R. Womac, C. Igathinathane, P. I. Miu, Y. T. Yang, D. R. Smith, N. Chevanan, S. Sokhansanj, Direct measures of mechanical energy for knife mill size reduction of switchgrass, wheat straw, and corn stover, Bioresour. Technol. 100(24) (2009) 6578-6585.

[16] S. Mani, L. G. Tabil, S. Sokhansanj, Specific energy requirement for compacting corn stover, Bioresour. Technol. 97(12) (2006) 1420-6.

[17] P. Haro, P. Ollero, A. L. Villanueva-Perales, A. Gomez-Barea, Thermochemical biorefinery based on dimethyl ether as intermediate: Technoeconomic assessment, Appl. Energy 102 (2013) 950-961.

[18] R. Braun, A. Wellinger, In Potential of co-digestion, IEA Bioenergy, Task, 37 (2003).

[19] O. Guo, Y. Li, J. Bai, G. Yang, Z. Zhou, G. Ren, Y. Feng, Effect of temperature on gasification characteristics of mixture of chicken feces and crop residue, Journal of Northwest A \& F University Natural Science Edition 37(6) (2009) 137-144.

[20] L. T. Biegler, I. E. Grossmann, A. W. Westerberg, Systematic methods for chemical process design, 1997.

[21] H. P. Loh, J. Lyons, C. W. W. Iii, Process Equipment Cost Estimation, Final Report, Office of Scientific \& Technical Information Technical Reports (2002).

[22] X. D. Pu, L. W. Deng, Y. Yong, S. Li, Z. Y. Wang, Economic benefit analysis on large and 
middle-scale biogas plants with different heating methods, Transactions of the Chinese Society of Agricultural Engineering 26 (7) (2010) 281-284.

[23] B. H. Gebreslassie, M. Slivinsky, B. Wang, F. You, Life cycle optimization for sustainable design and operations of hydrocarbon biorefinery via fast pyrolysis, hydrotreating and hydrocracking, Comput. Chem. Eng. 50 (2013) 71-91.

[24] J. Krischan, A. Makaruk, M. Harasek, Design and scale-up of an oxidative scrubbing process for the selective removal of hydrogen sulfide from biogas, J Hazard. Mater. 215 (2012) 49-56.

[25] E. Ryckebosch, M. Drouillon, H. Veruaeren, Techniques for transformation of biogas to biomethane, Bioresour. Technol. 35(5) (2011) 1633-1645.

[26] Y. Xu, Y. Huang, B. Wu, X. Zhang, S. Zhang, Biogas upgrading technologies: Energetic analysis and environmental impact assessment, Chinese J. Chem. Eng. 23(1) (2015) 247-254. [27] X. Liu, Y. Huang, Y. Zhao, R. Gani, X. Zhang, S. Zhang, Ionic Liquid Design and Process Simulation for Decarbonization of Shale Gas, Ind. Eng. Chem. Res. 55(20) (2016) 5931-5944.

[28] C. A. Grande, A. E. Rodrigues, Biogas to fuel by vacuum pressure swing adsorption - I. Behavior of equilibrium and kinetic-based adsorbents, Ind. Eng. Chem. Res. 46(13) (2007) 4595-4605.

[29] H. Ruan, Z. Yang, J. Lin, J. Shen, J. Ji, C. Gao, B. Van der Bruggen, Biogas slurry concentration hybrid membrane process: Pilot-testing and RO membrane cleaning, Desalination 368 (2015) 171-180.

[30] H. Yu, Q. Wang, K. E. Ileleji, C. Yu, Z. Luo, K. Cen, J. Gore, Design and analysis of geographic distribution of biomass power plant and satellite storages in China. Part 2: Road delivery, Biomass Bioenergy 46 (2012) 785-792.

[31] A. Hussain, M.-B. Hagg, A feasibility study of $\mathrm{CO}_{2}$ capture from flue gas by acilitated transport membrane, J. of Membrane Sci. 359(1) (2010) 140-148.

[32] D. De Clercq, Z. Wen, F. Fei, Economic performance evaluation of bio-waste treatment technology at the facility level, Resour. Conserv. Recy. 116 (2017) 178-184.

[33] X. Zhang, C. Li, C. Fu, S. Zhang, Environmental impact assessment of chemical process using the green degree method, Ind. Eng. Chem. Res. 47(4) (2008) 1085-1094. 